\title{
ISLAMISM IN MALAYSIAN POLITICS: THE SPLINTERING OF THE ISLAMIC PARTY OF MALAYSIA (PAS) AND THE SPREAD OF PROGRESSIVE IDEAS
}

\author{
Wan Saiful Wan Jan*
}

\begin{abstract}
This paper argues that the splintering of Parti Islam Se-Malaysia (PAS) was due to an internal ideological and political battle between conservatives and progressives in PAS. The battle between the two schools traces back to the early 1900s and the debate between the Kaum Muda and Kaum Tua. This paper focuses on the important events and past leaders that shaped PAS into a nationalist-conservative movement with an authoritarian leadership. In 2015, progressive PAS leaders left to form Parti Amanah Negara (AMANAH) as an alternative, ideologically different Islamist Party. The split prompted a growth of interest in Islamist progressive ideas beyond the realm of political parties, with more public discourses taking place at all layers of society, including amongst intellectuals and various organisations, such as civil societies and publication houses.
\end{abstract}

Keywords: Islamism, Parti Islam Se-Malaysia (PAS), Conservative Muslim, Parti Amanah Negara (AMANAH), Progressive Muslim, Political Islam, and Authoritarian Leadership.

\section{Introduction}

Malaysian politics has always been coloured by religion, especially by Islam. This has been the case for centuries. Some suggest that Islam has influenced the governance of the country since the 1400s, when the Sultanate of Malacca was first founded. As the country grows and evolves, Islam has shaped Malaysia in more ways than one, covering sociocultural aspects, politics, and even the economy. In modern times, Islam became more strongly mixed with Malay nationalism and the struggle for independence, especially from the late $1800 \mathrm{~s}$ and early 1900s with the arrival of Muslim traders and scholars from the Middle East and their settling down in the country. The rise of Islamism in neighbouring Indonesia in the first half of the 1900s further enabled the exchange of ideas between activists and intellectuals from the two countries.

Today, Islam continues to be a strong influence on Malaysian politics, with 
all political parties, including the parties whose members are mainly nonMuslim, regularly debating Islam's role in public policy. However, when it comes to political Islam, the political party that is most frequently studied and cited is the Islamic Party of Malaysia (PAS). It has a long history that predates independence. More recently the party made headlines in 2015 when a group of their national leaders left to form a new party called Parti Amanah Negara (AMANAH) (National Trust Party).

This paper explores the evolution of political Islamism in Malaysian politics by looking at PAS and the internal debates within the party that eventually led to the formation of AMANAH. The paper argues that the split was due to an ideological battle between conservative and progressive Malays both within the party and in broader society and that the split was not at all surprising given the fact that the battle between these two schools has been ongoing since the early 1900s. Tracing the roots of the split to the Kaum Muda vs Kaum Tua debate, the paper suggests that PAS has always been a nationalist and conservative party. Attempts to bring the party towards a more modernist and progressive outlook have never succeeded. More often than not, those who have tried to change the party from its conservative stance are the ones who have ended up sidelined, if not removed. This was the case when the progressive figures in PAS were told, in the 2015 party election, that their time is up, forcing them to split from PAS to form AMANAH.

To explain the events that led to the split, it is necessary to examine the ideological and political battles within PAS itself. This paper explains how two key figures were responsible for shaping PAS into the nationalist-conservative movement it is today: PAS's third president, Burhanuddin al-Helmy, who injected collectivism into an already conservative party, and the fifth president, Yusuf Rawa, who added Iranian Revolution-inspired Islamism into the mix. This combination of collectivist and Islamist ideas gave the top leadership in PAS almost complete and total control of their obedient members, with no mechanism for the check and balance of power amongst the top leaders.

This collectivist-Islamist nature mirrors closely the attitude of the party's grassroots conservative membership, which is at odds with the more modernist ideals of good governance, transparency, checks and balances, and decentralisation championed by progressives. Despite being active in PAS for decades, progressives have failed to properly structure and strategise their work within the party to spread their progressive ideas to the broader membership of the party, as contrasted with the more organised and strategic approach of the nationalist-conservatives. This paper argues that as a result, the progressives lost the internal debate and were unceremoniously removed from the party's leadership in 2015. 
The paper also presents a new argument concerning Islamism in Malaysia: that the two oft-celebrated leaders who are usually labelled progressive, Burhanuddin al-Helmy and Yusuf Rawa, were actually the ones who created the foundational infrastructure for the centralised authoritarian culture of PAS that we see today.

The paper concludes by suggesting that the thinking of these two figures continues to flourish in PAS today and differs significantly from the ideals of AMANAH, which are influenced more by modern-day Islamists from Tunisia. As a new party launched only in September 2015, AMANAH is still crafting a coherent description of its progressive ideology. However, the splitting of PAS and the birth of AMANAH have enabled the discourse on progressive Islamism to spread to the masses, which means that even if AMANAH fails electorally, progressive Islamist ideas are likely to stay for the foreseeable future.

\section{Setting the Scene: Islamism Prior to Independence}

Islam has long existed in Malaysian politics, even before the country was officially formed. However, Islam's appearance in public discourse in a more organised and political sense can be mainly traced back to the colonial period. When the Pangkor Treaty was signed on 20 January 1874, a new structure of governance was formed in what is today Malaysia. British officers took over the running of the government, leaving the administration of religion to the Malay Rulers. For the first time in the history of the land, a separation between religion and the state was created. However, the operations of the religious, bureaucratic network were still British-sponsored, despite being led by the Malay Sultans in their respective states and manned by Malay ulama. This eventually led to a more structured discourse on the role of Islam in public life, organised into two quite distinct and contesting groups, one working from within the formal bureaucracy and another from outside, from the relative freedom of the Straits Settlements of Penang and Singapore, where "they had no worry about Islamic religious censorship." Farish A. Noor explains the situation ${ }^{2}$ as follows:

Political Islam, therefore, developed in fits and starts during [the] colonial era. The traditionalist religious elite found they could entrench themselves and consolidate their influence even further by working within the British bureaucratic network. The Islamist reformists, on the other hand, found that their activities faced fewer restrictions while they worked under the British (secular) civil law of the Straits Settlements. In time, a vibrant and heterodox body of Islamic and 
Islamist discourse developed. The differences between these schools of thought finally came out into the open with the confrontation between the Kaum Tua (older generation of traditionalists) and the Kaum Muda (younger generation of modernists) in the $20^{\text {th }}$ century.

The theological differences between the two groups - the Kaum Tua and the Kaum Muda - have been summarised by Maszlee Malik. ${ }^{3}$ This essay's focus is on the divergent strategies and the political thought of the two groups; as will be seen later, it is these differences that planted the seeds that led to the splintering of AMANAH from PAS in 2015.

The priorities and the approaches taken by these two groups have always been different, yet they both share a commitment to propagate Islam and to campaign for the adoption of Islamic values in public policies. At their core, both groups are still quite "traditional" in that both believe society must be brought back to the Islamic value system outlined by the Qur'an and Hadith. Any differences between them are mainly in the context of how the texts of the Qur'an and Hadith are interpreted when developing strategies and tactics to achieve that aim. In the context of fighting for independence, both Kaum Tua and Kaum Muda shared the desire to see an independent Malaya, although antiBritish sentiment was less strong among the Kaum Tua, as reflected in how they positioned themselves within the power structure of the time.

The Kaum Tua, as the name implies, was more conservative and traditionalist. They mainly worked from within the British-sponsored bureaucracy, aligning themselves with the traditional Malay power structure, with the Sultan at the top. The enjoyed authority by virtue of their presence in the official government machinery set up by the British, with all the trappings of power that came with it, thereby entrenching their control of the formal religious bureaucracy.

The Kaum Muda, on the other hand, took a more activist approach. Although they did take up high-ranking government positions and became part of the official power structure, ${ }^{4}$ for the most part they opted for a more grassroots strategy, setting up their own religious schools or madrasahs through which they could grow their ideas and build their support networks organically. Overall, their authority was not rooted in a legal or administrative structure, but in the strength of their ideas and the persuasiveness of their arguments.

When it comes to the political ideas championed by the two groups, there are distinctive features that are relevant to the topic being discussed here. The Kaum Muda were influenced by the modernist and reformist thinking that originated with the teachings of Jamaluddin al-Afghani, Muhammad 'Abduh and Muhammad Rashid Ridha, who were all actively propagating reformist thinking from Egypt., ${ }^{5,6}$ They believed in the importance of reason and 
intellectualism, combining traditional methods with more modern and secular knowledge. For them, the doors of ijtihad (independent reasoning) were always open. ${ }^{7}$ The Kaum Muda were also seen as more liberal in their views, openly championing concepts that were relatively new during that time, such as female emancipation. ${ }^{8}$ However, the word 'liberal' here is used in a relative sense, referring to the Kaum Muda being 'more liberal' compared to the Kaum Tua. It does not imply that the Kaum Muda were liberal as understood in today's Western philosophical discourse.

On the other hand, the Kaum Tua were less open to the utilisation of modern knowledge in religious issues. Coming mainly from the rural, oralbased pondok education system that deployed a more literalist interpretation of texts, they secured their presence in society through regular talks and teaching activities delivered at local village surau and mosques scattered throughout the country. Their rise as a distinct group within the Malay society was catalysed by the desire to resist the spread of reformist ideas by the Kaum Muda, whose modernist thinking was gradually and increasingly challenging their position in society. The Kaum Tua was also much closer to the establishment, especially the Sultans, which made them, more often than not, a defender of the Malay monarchy. In return, the monarchy and the establishment were usually quite comfortable with them.

The Kaum Tua-Kaum Muda contestation occurred mainly in the early 1900s. As the country became more focused on achieving independence from Britain, and subsequently when more effort was spent on filling the administrative void left by the British after independence in 1957, the public spat between Kaum Muda and Kaum Tua subsided. On the whole, the Kaum Tua were seen as the victor because their grip on the establishment continued. However, as pointed out by Mohamed Osman: ${ }^{9}$

...in the long term, the Kaum Muda's impacts on Malay society was felt in both the religious and political spheres. Kaum Muda activism planted the seeds for the growth of a Malay-Muslim intelligentsia, which tried to diagnose and analyse the circumstances that arose among Malays due to colonialism. This led to an increasing awareness among Malays of the importance of education. While the Kaum Muda themselves were less politically active, their successors utilised the revivalist spirit to form political organizations such as Hizbul Muslimin (HM), Kesatuan Melayu Muda (KMM), and the Parti Islam Se-Malaysia (PAS). 


\section{From Conservatism to Leftist Nationalism}

The origin of PAS is rather convoluted, but the official line is that it was founded on 24 November 1951, at a meeting of Malay scholars and representatives from various Islamic associations in Butterworth, Penang. ${ }^{10}$ The meeting was actually the third Ulama Congress, which itself had its origin in the desire of the dominant (and only) Malay nationalist party at that time, the United Malays National Organisation (UMNO), to improve its public reputation. UMNO was getting worried that it was losing the support of conservative Malay Muslims and saw the need to reposition itself as a champion of Islam. Thus, UMNO, under the presidency of Dato' Onn Jaafar, sponsored the first Ulama Congress (Perjumpaan Alim Ulama Tanah Melayu) on 20-22 February 1950, the second on 23 August 1951 and the third later that same year. The purpose was to bring together conservative Muslim scholars to discuss the steps that they needed to take in moving towards independence. When the Ulama Congress was held for a third time on 24 November 1951, the delegates agreed to the formation of the Persatuan Islam Se-Malaya (Pan-Malayan Islamic Organisation), and this was the starting point for PAS.

PAS's foundation as part of an UMNO strategy to attract conservative Malay Muslim voters is readily apparent, entailing that the party's founding ideology was essentially Malay conservatism. Not only does PAS trace its origin to Dato' Onn's strategy to reposition UMNO as the champion of conservative Islam, but its first President was Haji Ahmad Fuad, who simultaneously held the position of head of UMNO's Religious Affairs Bureau, thereby providing a direct linkage to UMNO's head office. In other words, PAS started off as an entity that was led by the Head of UMNO's Religious Bureau.

In addition to Malay conservativism, the founding ideas of PAS revolved around Malay nationalism and Malay unity, again similar to UMNO's founding principles. In fact, when accepting the presidency of the party, Haji Ahmad Fuad gave a speech entitled 'Kita Laksana Sampah, Kerana Tidak Bersatu' (We are but flotsam, for we remain disunited) ${ }^{11}$ an obvious attempt to call for Malay unity.

PAS's Malay conservatism became clear soon after its founding. On Ahmad Fuad's agenda was bringing PAS closer to Dato' Onn's new party, the Independence of Malaya Party (IMP), after Dato' Onn left UMNO in 1951 because UMNO's conservative membership rejected his idea to turn UMNO into a non-communal party. He set up the IMP as his new platform to promote multiracialism. ${ }^{12}$ When Ahmad Fuad proposed that PAS cooperate with IMP at a special meeting on 26 September 1953, he too was defeated by PAS's conservative members. The majority of PAS members were not ready to become non-communal. They preferred instead to take part in another initiative led by 
the ethnic-based UMNO and its junior partner, the also ethnic-based Malayan Chinese Association (MCA). ${ }^{13}$ This defeat led Ahmad Fuad to resign from PAS - the first indication that it was not easy for anyone, even the founding president, to go against the conservative Malays within the party. Right from the start, when they had to choose a political partner, PAS preferred UMNO's communalism over other options.

When Burhanuddin al-Helmy became PAS's third president in 1956, he solidified the position of nationalism within the already conservative party. Burhanuddin outlined in his maiden speech as PAS president that the basis of his (and hence PAS's) struggle must be Malay nationalism, that the Malays are the owner of the country, and that the Malay language must be made the national language. ${ }^{14} \mathrm{He}$ also went on to say that he opposed the granting of citizenship using the jus soli principle, as he felt that the rising number of non-Malays in Malaya could create "the risk of treasons that will endanger this nation's independence." $15 \mathrm{He}$ and PAS did not believe the non-Malays could be loyal citizens of the country. This scepticism is not surprising because Burhanuddin was always known to be one of the most outspoken Malay nationalist leaders in the country at that time.

Equally important was how Burhanuddin tried to transform PAS from a conservative to a leftist party. When he was asked why he wanted to join PAS, he reportedly said that once he assumed the presidency of PAS, "it would be easier for me to inject a leftist soul into it." ${ }^{16}$ Even his entry into PAS was undertaken after obtaining the blessings of the leaders of the socialist-Marxist party, the Partai Rakyat Malaya (PRM). ${ }^{17}$ As far as the PRM leaders were concerned, Burhanuddin's entry into PAS was beneficial to their wider leftist cause, and PRM's president at that time, Ahmad Boestamam, said to him "it is alright for us to sit in different corners, so long as it is on the same rug." 18 Indeed, as soon as he assumed the presidency of PAS in 1956, in his inaugural speech Burhanuddin immediately started the transformation process by saying: "The healthy forces of nationalism, religion and socialism in society must be utilised, brought together from now... The similarities between the three must be upheld, blended and strengthened..."19

Various studies have explained that Burhanuddin was not leftist in the Marxist-Leninist sense. The term 'left' at that time was used as a somewhat generic term to describe those who chose to strive for independence by not cooperating with the British. ${ }^{20,21,22}$ The writings and speeches of Burhanuddin suggest that Burhanuddin would fit more comfortably into the category of a centre-left collectivist, and lean more towards social democracy. As explained by Berman and Dettke, social democracy is built on a belief in the primacy of collectivism and represents a non-Marxist vision of socialism. Social democrats 
believe in the need to use, and the justifiability of using, coercive government powers to create social change and to ensure conformity towards collective ideals. ${ }^{23}$ With that ideological leaning, Burhanuddin planted the seeds for a belief in a religiously-guided collectivist governance, a robust power centre to govern society. He coined a new term to describe his belief: "theocratic socialism." ${ }^{24}$

However, Burhanuddin still had to work within a party that was essentially Malay conservative and Islamist in nature. The conservatives still had a hold on the party's machinery and were able to rally behind the conservative deputy president, Zulkifli Mohamad. Even though Burhanuddin held the top position in the party, the conservative flame was kept alive by Zulkifli. While Burhanuddin was the public face of PAS, internally it was Zulkifli who was regarded as the true representative of PAS ideological beliefs and he regularly warned party leaders to not deviate from the real cause of conservative Malay Islamism. It was in this era that the distinction between the "original" conservative PAS and the so-called "imported alien ideas" was sparked. The conflict was not apparent, but the seeds were planted then. ${ }^{25,26}$

\section{Islamisation of Authoritarianism}

Upon Burhanuddin's demise, the PAS presidency passed to a charismatic Malay nationalist leader, Asri Muda. Farish Noor provided a good overview of the Asri years. ${ }^{27}$ Asri was charismatic, more due to his oratory than intellectual or administrative skills. Coming from a predominantly Malay Muslim family and social background, Asri turned PAS into a party whose concerns centred around the Malay agenda. He brought PAS closer to UMNO, even joining the Barisan Nasional coalition from 1972 to 1978. Asri's Malay-nationalist attitude created a rift in the party, however, with an increasing proportion of the PAS membership accusing him of taking the party away from their original Islamist agenda. Indeed, his singular focus on Malay ethno-nationalism caused him to miss an important development within wider Islamist activism circles in Malaysia during the 1970s: this period saw new Islamist groups arise, including the likes of the Islamic Representative Council (IRC), the Muslim Youth Movement of Malaysia (ABIM), and Darul Arqam. While these groups started to steal away PAS's claim to be the representative of Islam in the country, Asri continued to mould PAS into a Malay-centric party. As a result, PAS started to lose its grip on Malaysian Islamists. This increased the strength of protest against Asri's leadership from within the party.

This protest gradually paved the way for the rise of a new group within PAS, the ulama led by religious scholars such as Yusof Abdullah Ar-Rawi (better 
known as Yusof Rawa), Abdul Hadi Awang, and Nik Abdul Aziz Nik Mat. The 1979 Iranian Revolution was pivotal in this development. It opened the eyes of some PAS leaders about the potential success of a more revolutionary approach. They started to question Asri's ethno-nationalism more vocally, arguing that his methods were un-Islamic. Eventually, this ulama group removed Asri from his presidency on 23 October 1982. Yusof Rawa took over as the next president, marking the beginning of a significantly new era in the party's ideological evolution.

Under Yusof, the party radically changed from a movement with only a narrow Malay agenda to one that promoted pan-Islamism. Over time, the influx of ABIM and IRC activists into the party assisted Yusof's agenda to turn PAS into a staunchly pan-Islamist party. These activists brought with them a more structured system to turn members into cadres, using an internal education system inspired by the Muslim Brotherhood. Influenced by the thinking of Syed Qutb, ${ }^{28}$ Yusof used strong tactics to attack UMNO and others whom he deemed as being on the "other" side, openly and repeatedly drawing lines between what he labelled Islamic and un-Islamic (Islamic vs. $k u f r$ ).

A rising firebrand from Terengganu called Abdul Hadi Awang strengthened Yusof's approach. Hadi caused a storm when he issued an edict (commonly called the Amanat Haji Hadi) implying that those who support the UMNOled Barisan Nasional are supporting a kufr agenda. Albeit indirectly, Hadi was the first to push to the forefront of Malaysian politics the takfiri approach that had become widespread in the Middle East at that time. ${ }^{29}$ Despite the division he caused in broader society, his radical approach helped positioned PAS's struggle as a holy jihad, spreading the belief that PAS is Islam and Islam is PAS, because PAS was the only party campaigning for the introduction of Shari'ah law (especially hudud). Hadi positioned PAS's political enemies as the enemies of Islam, thereby directly contributing to making PAS an exclusivist party.

During this ulama era, PAS did not just adopt radical Islamism as its ideology but also underwent critical structural changes, too. Together with his supporters, like Fadzil Muhammad Noor, Abdul Hadi Awang, Nik Abdul Aziz Nik Mat, and many more, Yusof was the first to propagate the claim that the mantle of leadership should be assigned to religious scholars (ulama). Inspired by the Iranian revolution, the ulama group promoted a concept that was eventually known as "Kepimpinan Ulama" (Leadership by Ulama). The crux of this idea was that the ulama are chosen by God to inherit the mantle of leadership left by Prophet Muhammad, and therefore should lead the party. Being an ulama was made a pre-requisite before anyone could assume a top post in PAS and in 1983 a constitutional amendment was passed to set up an unelected Majlis Syura Ulama (Ulama Consultative Council) to be PAS's highest layer of authority, 
unaccountable to party members. Yusof also created the post of Mursyidul Am to play a role akin to the Iranian Grand Ayatollah, again with no mechanism for accountability to members. The claim was that at that position, the post-holder was responsible and accountable only to God.

It was ultimately the conservative ulama group who benefited from Yusof's actions. Nevertheless, its grip on the party created concerns in the eyes of some party leaders. When a vocal critic, Abu Bakar Hamzah, criticised Yusof's approach, his membership was suspended in $1986 .{ }^{30}$ The ulama group, even though they rose to power by challenging Asri's authority and legitimacy, were not willing to entertain or allow any challenge to their own authority and legitimacy.

Yusof's presidency, and the era of leadership by ulama that he started, was a watershed moment that made PAS into what it is today. Before Yusof, PAS had two presidents, Ahmad Fuad and Asri, who were forced by the party to leave their posts, as described above. But Yusof started a new norm, whereby top party leaders began to be regarded as chosen by God to inherit the leadership positions left by the Prophet. The creation of the Majlis Syura Ulama and the post of Mursyidul Am were major steps in that direction, creating positions with no mechanism of accountability to provide checks and balances against the occupants of those posts. Yusof and his supporters paved the way for PAS leaders to become holy men.

Yusof's success was quite remarkable. While Burhanuddin al-Helmy had only been able to plant the seeds of his theocratic socialism, but was unable to mould the party into a movement to pursue his vision, Asri Muda later taking the party in a different direction, Yusof Rawa and his supporters successfully used Islam not just to rise to power, but to institutionalise their grip on power by removing democratic checks and balances. The creation of the Majlis Syura Ulama and the post of Mursyidul Am meant that the ulama group became unassailable, free to use their powers to shape the party from the centre. In a way, Yusof completed what Burhanuddin started, namely the institutionalisation of theocratic socialism, a centralised structure that is unaccountable to members because it claims to be answerable only to God. That structure was safeguarded not just with the party's constitution, but also with religion. The top leaders could now demand obedience (wala') from party members and determine what the correct party ideology (fikrah) should be. By institutionalising their control and couching their actions in religious terms, Yusof Rawa "Islamised" a soft version of authoritarianism in the party.

Fadzil Noor took over the presidency from Yusof in 1989. He was touted as an inclusive leader and under him PAS became a respected national party, personified by his willingness to work with others, including non-Muslim parties 
and civil society organisations. During Fadzil's era of inclusiveness, more progressive Islamist figures entered into the picture, rising up through the ranks to hold central positions in PAS. Even if they did not win party elections, Fadzil would appoint them into chief posts in the party at various levels. ${ }^{31}$ However, these progressive figures, and Fadzil himself, did not do anything to change the core essence of the party. It was still led at the top by an unaccountable set of leaders. The post of Mursyidul Am became even more revered, while the takfiri culture introduced by Hadi continued to simmer in the background. The concept of leadership by ulama was strengthened even by the progressives. Moreover, the party, including the progressives, continued to campaign for what was essentially Burhanuddin's theocratic socialist ideals - that society and individuals should be guided from the centre using the coercive authority of either the state or (within the party) the party's leadership. The only difference was that, while Burhanuddin used relatively secular language to promote his ideals, Fadzil's era saw increased usage of Arabic terms, creating the impression that collectivist ideals were in fact Islamic ideals.

When PAS became united in their agenda - usually when challenging UMNOthings progressed smoothly, the progressives even serving to enhance the ulama's worldview. Thus, the progressives played a pivotal role in solidifying the ulama's grip on the party. They put their complete trust and hope in two people, Fadzil Noor and the Mursyidul Am, Nik Abdul Aziz Nik Mat, believing that they would steer the party towards a progressive direction, meaning there would be no need to change the party structure into one that was more democratic. ${ }^{32,33}$ However, as will be seen at the end of the next section, their trust in the benevolence of the authoritarian structure faltered when these two figures passed away. It was only then that the progressive Islamists discovered that, without the protection of Fadzil and Nik Aziz, their positions were vulnerable and their ideas unaccepted within the party. They were merely temporarily tolerated.

\section{Tolerant Conservatives}

As the only political party that openly champions a strongly Islamic agenda, PAS is the most palpable party for anyone with interests in political Islam. Even though, as explained above, PAS is essentially a conservative and traditionalist party, progressive Islamist activists were still able to find space in the party. Although this has been the case from the start, in the 1970s and 1980s, many more activists from other Islamic organisations joined PAS, including those from ABIM and IRC. In the early 1980s, they played an important role in removing Asri and installing Yusof to lead the party. Soon after that, they were pivotal in 
ensuring that the concept of leadership by ulama was embedded in the party both ideologically and structurally. Throughout this period the progressives never organised themselves into a distinct group, preferring to work within the established party structure.

The word 'progressive' in this context is not easy to define. Various factors come into play. In general, many of the progressives within PAS show elements of Kaum Muda thinking, in the sense that they call for new opinions (ijtihad) to be formed when dealing with contemporary political challenges and are more comfortable with the use of reason and logic not tied to dogma. They show interest in wider policy challenges, preferring to discuss and define the concept of an Islamic state using theories of good governance and liberal democracy. They are also more open to engaging with those from outside PAS, including non-Muslims, as well as to venture into issues that are much broader than the traditional legalistic Islamic state agenda. They have tried to push PAS away from the narrow pursuit of hudud law and do not use the radical takfiri approach against their political opponents. These factors, to varying degrees, distinguish them from the mainly conservative PAS members and their pondok-educated leaders.

Following the Reformasi years of the late 1990s and early 2000s, these progressives found themselves increasingly able to shape PAS's political agenda and public image. Firebrands like Abdul Hadi Awang and Ulama Wing Chief, Haron Taib, gave way to them and even altered their own radical attitude to suit the rising influence of the progressives within the party. PAS as a whole was quick to adapt, and the new political strategy of the party worked well for the progressives. From the divisive and exclusive holier-than-thou party, PAS was seen as having been transformed into an inclusive and progressive party that was increasingly accepted by the electorate across both ethnic and religious boundaries.

One early example of how the conservatives were willing to tolerate and accommodate the new trend took place in 1999, when the party was faced with the real possibility of a sea change in Malaysian politics following the 1998 ousting of Deputy Prime Minister Anwar Ibrahim from UMNO. Around 20 members of the PAS central committee travelled to the Islamic Foundation in Markfield, United Kingdom, to attend a meeting with renowned Islamic scholars Yusof al-Qaradhawi, Rached Ghannouchi, Khurshid Ahmad, and Kamal Alhelbawy. This author was one of the organisers of that meeting, and the top two items on the agenda were the acceptability of working with the Chinese-majority Democratic Action Party (DAP) and how to handle the possibility of Wan Azizah Wan Ismail, Anwar's wife, becoming Leader of the Parliamentary Opposition. 
In that meeting, conservative figures like Abdul Hadi Awang, Haron Taib, central committee member Hashim Jasin, and several others strongly opposed both ideas. They relented, however, after all the invited scholars argued that these were Islamically-justified and necessary. The fascinating point to observe during that two-day meeting was the interaction that occurred on the sidelines, privately, between PAS leaders. The differences between Fadzil on the one side and Hadi and Haron on the other were evident. Fadzil worked hard to make the new partnership happen, but Hadi persistently challenged his views by saying that the moves were not Islamic.

Nevertheless, and to their credit, every single person in that meeting who initially opposed the proposal joined hands to present a united front after the meeting. Once a majority decision was made, everyone, including the conservatives, publicly supported the new political partnership. The conservatives were willing to give way to the new ideas - or else they may have realised that they did not have the strength to resist the changing national tide. They nevertheless tolerated the progressives.

In the early 2000s, UMNO, particularly its President and Malaysia's then Prime Minister, Mahathir Mohamed, alleged that PAS had no real plans for governing the country. In response, Fadzil formed a team to draft a document outlining PAS's vision of an Islamic state. He wanted to see a document that provided a detailed description of the policies that PAS would introduce if they were to come to power. ${ }^{34}$ His untimely demise on 23 June 2002 changed this scenario, however, with the conservative Abdul Hadi Awang taking over as president. He asked arch-conservative, Haron Din, to continue drafting the document. Haron's committee eventually produced the Dokumen Negara Islam (Islamic State Document), which was released on 12 November 2003. However, the content was well short of any real policy prescription. It was just a short booklet with broad outlines of PAS's vision for an Islamic state and a list of simple, one-line bullet point policy statements. This was far short of what the late Fadzil originally asked for.

\section{The Progressives: Determined but Unorganised}

Unsatisfied with the seeming inability of the party to chart a clearer vision, the progressives decided to build the Dokumen into more concrete propositions. They lobbied from within the party hierarchy and persuaded the party to adopt the theme 'Kerajaan Beramanah, Adil dan Bersih: Ke Arah Negara Berkebajikan' ('Honest, Fair and Clean Government: Towards Negara Berkebajikan'). On 3 June 2011, Hadi announced during his policy speech at the PAS annual general 
meeting that the party would make the creation of a "Negara Berkebajikan" their top agenda. This was followed by the appointment of a leading progressive figure, vice president Salahuddin Ayob, to head a team detailing what was meant by the concept, resulting in the publication of another booklet, 'Negara Berkebajikan: Tawaran PAS' (Negara Berkebajikan: PAS Offers) on 11 December 2011. The term "Negara Berkebajikan" is often confused with the Western welfare state, but PAS translated this term as "Nation of Care and Opportunity," distinguishing it from the costly redistributionist welfare state. ${ }^{35}$ They also toned down the call for an Islamic state and the implementation of Shari'ah, including hudud law. For the progressives, this was a significant achievement because their ideas were now the official policy of the party; they had managed to shift PAS away from its decades-old slogan of an Islamic State.

In their haste to promote Negara Berkebajikan, however, the progressives missed one primary development that was simmering quietly in the background: UMNO was chiding them for not including the hudud as part of the promised Negara Berkebajikan and the conservatives were becoming agitated. The conservatives felt that the Negara Berkebajikan proposition was taking PAS too far away from what was supposed to be its core purpose, the creation of an Islamic state that upholds the hudud law.

Oblivious to conservative resentment, the progressives pushed ahead with two even more radical proposals that could change PAS in very significant ways. First, they wanted PAS to open its membership to non-Muslims, while second, they wanted to shift PAS away from leadership by ulama to a more inclusive paradigm.

The responsibility for pushing these ideas out to the wider membership was taken up by Mujahid Yusof. The son of Yusof Rawa, Mujahid became a PAS central committee member in 2005. Before that, he played an important role in helping PAS reach out to non-Muslim voters and in forming the PAS Supporters Club in 2004. On 7 November 2008, he presented a five-point proposal to PAS central committee: ${ }^{36,37}$

1. To amend the PAS constitution so that non-Muslims can become members;

2. To turn the PAS Supporters Club into a "wing" of the party;

3. To upgrade the party's National Unity Bureau into a department until the new "wing" can function fully;

4. To put up non-Muslims as PAS candidates and to appoint them into official posts in state governments controlled by PAS;

5. To appoint non-Muslims as senators and to other important positions within the party. 
Mujahid's proposals were accepted and steps were immediately taken to implement them. Finally, PAS announced the formation of the Dewan Himpunan Penyokong PAS on 23 May 2010, specifically for non-Muslims. This unprecedented decision institutionalised non-Muslim entry into the party. Mujahid was clearly pleased by PAS's historic acceptance of his suggestions, seeing it as the culmination of an agenda that was started by his father when the latter set up the Chinese Consultative Council (CCC) within PAS in 1985. Mujahid also published a book in 2009, Wajah Baru Politik Malaysia (The New Face of Malaysian Politics), to help document and disseminate his ideas on why it was important for PAS to accept non-Muslim members.

Mujahid then went further in his attempt to transform PAS. In 2010, he released a book entitled Menuju PAS Baru: Krisis, Peluang dan Dinamisme (Towards a New PAS: Crisis, opportunity and dynamism). This book was followed by another in 2012, Rejuvenasi PAS: Idea, Realiti, Aplikasi (Rejuvenating PAS: Ideas, reality, application). In both, he discussed an even more touchy subject: the need to reform the Leadership by Ulama concept. In the first book, he deliberated on it only lightly, saying that the original principle as introduced by his late father was not meant to elevate any one person, but was about the leadership of the Majlis Syura Ulama collectively. He also argued that the Majlis Syura Ulama was formed in order to curb centralisation of power in the hands of the president, as practised by Asri before 1982. ${ }^{38}$

In the second book, Mujahid provided a more forceful critique of the Majlis Syura Ulama. He argued that the body complicates the administration of the party because there are duplications of membership. It also reinforces the image that PAS is an overtly religious (rather than national) party. He also complained that discussions in the Majlis Syura Ulama were not transparent. Mujahid went on to propose two changes: the name of the body be changed to Majlis Perundingan Parti (Party Consultative Council) and membership be opened to non-ulama. ${ }^{39}$

\section{Return of the Conservatives}

While the progressives were busy promoting their ideas for reform within PAS, they underestimated the campaign conducted by the conservatives in the background to counter their ideas. The progressives assumed that, since they dominated the central committee and many of their suggestions had been accepted by the central leadership, including by President Abdul Hadi Awang, the party as a whole agreed with them. They knew that some of their suggestions were radically different from what PAS had been used to ${ }^{40}$ but they overlooked 
the need to persuade PAS's grassroot members. That was their biggest mistake. Over time, the space to engage with the party's grassroots became utterly controlled by the conservatives, who focused more on traditional issues like the need to implement the hudud and ensure Malays and Muslims would always have political control in Malaysia.

The conservatives were actively spreading their message through village mosques and internal events organised by the Dewan Ulama (Ulama Wing) and Dewan Pemuda (Youth Wing). Despite PAS's acceptance of non-Muslims into the party, the conservatives continued to preach doubts about the trustworthiness of non-Muslims. Despite the high-level discussions about the need to reform the Majlis Syura Ulama, the conservatives did not just defend the sanctity of the ulama and their position in the party hierarchy but went a step further, to sacralise them and position Abdul Hadi Awang's presidency as the symbol of leadership by ulama. Mujahid's ideas and initiatives provided a focal point for conservative retaliation. They now had a clear example of how progressives would, in their eyes, weaken the party (and therefore Islam) by bringing in non-Muslims and removing the ulama from the leadership. The conservatives had an advantage because, as religious scholars, they could give talks in village mosques, which they had been doing for decades, giving them longstanding access to PAS members. On 23 May 2009 , the conservatives organised a major national conference to celebrate the Silver Jubilee of Kepimpinan Ulama, despite it being two years late (the ulama took over the leadership in 1982). This author attended the conference. It was obvious that all speakers were using the platform to argue for the continuation of leadership by ulama and, more importantly, for the rejection of anyone who challenged the status quo or Abdul Hadi Awang's presidency.

The conference took place just two weeks before the party's Muktamar (annual general meeting), which saw a fierce contest for all posts other than the presidency. Of particular importance was the contest for deputy president. The nationalist conservative Nasharuddin Mat Isa was being challenged by two progressive leaders, Mohamed Sabu and Husam Musa. The conservatives went all out to defend Nasharuddin and other conservative leaders who were contesting other positions. Their persistent campaign and the Silver Jubilee conference worked; Nasharuddin won the party election. As noted by Farish Noor, ${ }^{41}$ the 2009 Muktamar was a "game changer in PAS in its internal politics as it led to the marginalisation of the modernist-reformists of the party, and the momentary return of the ulama faction instead." However, Farish was slightly mistaken because, as we shall see later, the return of the ulama faction was not momentary. Nevertheless, the stage was now set for a more public duel between the two groups. 
Parallel to that, with PAS President Abdul Hadi Awang being the firebrand cnservative that he is, he also began to show his true colours. Since he had inherited the presidency from the more accommodative Fadzil Noor, Hadi had also been accommodative at the beginning. However, uncomfortable with the dominance of the progressives in the PAS central committee, Abdul Hadi was not willing to continue the act. He started to ignore the decisions made by the central committee because the progressive majority often defeated him. Instead, he started to either appeal to the higher power of the conservative Majlis Syura Ulama or simply make decisions on his own. As explained by the Head of the Ulama Wing, Mahfodz Mohamed, ${ }^{42}$ "Let me be frank. The professionals were dominant. They are strong, and they can argue by giving facts, making it difficult to make decisions. That is why the President sometimes had to make his own decisions. He referred to the Majlis Syura only. If he were to bring his ideas to the central committee, he would certainly lose." ${ }^{43}$ Abdul Hadi Awang's attitude created confusion in the party, especially when other central committee members issued contradicting statements. This can be seen when PAS was dealing with a controversial decision taken by their coalition partner in the Selangor State Government to change the Chief Minister. Abdul Hadi Awang issued a statement supporting the incumbent, but his deputy, Mohamed Sabu, countered by saying this was only Hadi's personal view as the party had not yet discussed the issue officially. ${ }^{44}$ The conservatives in the party attacked Mohamed Sabu, accusing him of being disrespectful and disloyal to the president.

Malaysia then had her $12^{\text {th }}$ General Election on 8 March 2008; some commentators point to this date as the beginning of a more visible rift between the conservatives and the progressives in PAS. Khalid Samad, for example, has argued that the general election saw major flaws in Abdul Hadi Awang's commitment to keeping the party united as well as in the conservative commitment to maintaining a healthy relationship with coalition partners ${ }^{45}$ Khalid added that the relatively spectacular victory achieved by the opposition coalition - for the first time in the country's history, they won 82 of 222 parliamentary seats and five out of the 12 state governments - created a new challenge for PAS because the party had to quickly decide if they were willing to share power with the non-Malay Democratic Action Party (DAP). By working with DAP, PAS would be helping to install a non-Malay party into power by removing the Malay UMNO. Some conservative PAS leaders were uncomfortable with this and contemplated forming a coalition with UMNO in the states of Perak and Selangor to ensure the continuity of Malay power. The progressives, however, strongly resisted this. Abdul Hadi Awang was alleged to be privately open to the idea of partnering with UMNO and siding with the conservatives on the need to defend Malay power, despite saying differently to the progressive-dominated 
central committee and public. Since then he has continuously wavered between siding with or against UMNO.

PAS's 2011 and 2013 Muktamars widened the rift, with the conservatives persistently working in the background to increase their own support. Finally, during the Muktamar of 2015, held in Kuala Selangor, the battle that started in the 2009 Muktamar snowballed into a complete wipeout of the progressives from the central leadership. The conservatives dominated the 2015 Muktamar, openly challenging and sometimes insulting the progressives in their speeches, accusing them of being traitors to the PAS Islamist cause. This author was present at that Muktamar and witnessed how their comprehensive routing visibly shook the progressives. At that Muktamar, the conservatives returned in full swing to control PAS.

\section{PAS, Returned}

The conservatives were clearly prepared for the 2015 Muktamar. Their campaign was well coordinated, working nationwide under the guise of normal party activities organised by the various party structures that they control. At the Muktamar itself, they distributed a list of the candidates contesting on a conservative ticket and actively urged delegates to vote for those names. Whenever they were given the chance to speak, they did not shy from hinting at the need to remove the progressives from the central leadership. The progressives, on the other hand, were not prepared for this onslaught. From day one, they had no coherent strategy to propagate their ideas, especially to the lower layers of the party. Their presence was not institutionalised beyond the central committee. In short, the progressives were utterly unorganised. That led to the loss of the battle within the party, with PAS finally returning to its conservative-nationalist roots.

While PAS undoubtedly aims to create an Islamic state and implement Shari'ah law, to reduce the party to these issues is too simplistic a generalisation of the nature of one of the most successful Islamist parties in Southeast Asia. Shari'ah implementation is just one of their platforms and their zeal for it changes with time. In the bigger picture, PAS defines its conception of an Islamic state from a Malay conservative worldview; Malay conservatism was the raison d'etre and founding ideology behind the party, right from its birth under the guidance of Haji Ahmad Fuad, head of UMNO's Religious Affairs Bureau. Burhanuddin al-Helmy added collectivism into the mould, followed by Yusof Rawa's institutionalised authoritarian governance with an "Islamic" façade. At the core, PAS is a conservative collectivist party that is run from the centre by a group of religious elites who claim their authority is from God. 
Several studies have argued that PAS became more progressive thanks to the rise of progressive values within the party rank and file at the federal level. ${ }^{46,47,48}$ This, however, is a mistake, one that the PAS progressives themselves made. They assumed that by looking at the grass-top, they could describe the grassroots. In reality, the majority of PAS's membership remains conservative. These conservatives merely tolerated the progressives for a short while. They even 'used' (for lack of a better word) the progressives to engage non-Muslims and urbanites. ${ }^{49}$ This created a unique, albeit short, period where PAS was able to command support from both rural and urban voters, as well as from both Muslim and non-Muslim voters. This was the era when some observers described a "new PAS in [a] lounge suit and dinner jacket." conservatives remained the majority in the party and sustained their firm control of PAS through the Majlis Syura Ulama, the Dewan Ulama, and almost all the party machineries at the state and divisional layers. The progressives wrongly assumed that they were making deep and real changes in the party when in fact they were merely influencing things superficially, making tactical adjustments at the top. In 2015, the conservatives decided that enough was enough and, when they decided to strike, it was decisive.

With the toleration over, PAS is now back to its original nature: a Malay conservative and collectivist party with a powerful authoritarian centre. This was reaffirmed in the party elections during their Muktamar in April 2017, when conservative faces won all central committee posts.

\section{A New Party for Progressive Islamism}

Having failed in their attempt to make PAS embrace modern progressive ideas, the progressive PAS leaders quit the party en masse to form a new political party, called Parti Amanah Negara (AMANAH). Officially launched on 16 September 2015, AMANAH claimed to be the torchbearer of the positive legacies of PAS's Yusof Rawa, Fadzil Noor and Nik Abdul Aziz, emphasising inclusiveness, good governance, and harmonious coalition politics.

Of particular interest to AMANAH are the ideals and vision of the late Nik Abdul Aziz who, as Mursyidul Am of PAS, staunchly defended the progressives when they were under attack between 2008 and 2015. So intense is their admiration of Nik Abdul Aziz that, when they were going through the options for the name of their new party, one of the suggestions was 'Parti Nik Aziz'. ${ }^{51}$ However, the proposal was rejected on the basis that no party in Malaysia has ever been named after a person. Former PAS vice-president, Husam Musa, upon joining AMANAH on 31 August 2016 went a step further by saying "If Nik Aziz 
was still alive, he would join with me...because what is being championed by PAS now has deviated from what he championed..." ${ }^{52}$ AMANAH leaders also positioned themselves as being different from PAS in the sense that they do not adopt the harsh takfiri approach. The hints on this matter are usually subtle, as they do not want to openly accuse PAS of being a takfiri party. For example, in a speech, the chairman of AMANAH's Expert Advisory Council, Ahmad Awang, stated that Nik Abdul Aziz has never "uttered words similar to what was uttered by a PAS leader from Terengganu that has been popularised... as the 'Amanat Haji Hadi' ${ }^{, 53,54}$ By taking this line of attack, and by relating to the Amanat Haji Hadi indirectly, Ahmad and AMANAH in general are implying that PAS is now led by a radical takfiri leader who cannot possibly promote Islam in a multi-racial country like Malaysia.

The progressives have also used their ideals to shape the new party's structure. AMANAH's constitution states that membership is open to all, regardless of race and religion. It also states that the party champions good governance, moderation, openness and equality for women. In terms of organisational arrangement, they still follow the Iranian Revolution-inspired model brought into Malaysia's mainstream politics by Yusof Rawa, but with a twist to improve accountability. Similar to PAS's Majlis Syura Ulama, AMANAH has an Expert Advisory Council or Majlis Penasihat Pakar. ${ }^{55}$ Unlike PAS, however, AMANAH's Expert Advisory Council has only an advisory role; they are not given the power to supplant the elected central committee members. Perhaps learning from their experience in PAS, when Abdul Hadi bypassed the central committee and appealed directly to the Majlis Syura Ulama instead, AMANAH has provided a safeguard to ensure better checks and balances. Moreover, only five out of the 15 seats in the Expert Advisory Council are reserved for those with Islamic expertise. The others are supposed to be for those with other expertise.

In a study of the party, Maszlee Malik interviewed more than 100 AMANAH national and state leaders soon after the party's establishment. His findings confirmed that AMANAH's strategy is to position itself as an Islamist party "that is not PAS" because they feel PAS has become too conservative and may have even been penetrated by those who subscribe to extremist ideas. ${ }^{56}$ According to Maszlee, "the primary concerns of the party are derived from their appreciation of the concept of maqasid al-shari'ah (the higher objectives of Islamic Law). Their aim is to attain the well-being of the citizens by upholding the principles of justice, rule of law, freedom and good governance." They do not see Shari'ah as narrowly confined to the adoption of hudud law, but in the wider sense of ensuring a corruption-free government and the well-being of all, regardless of faith and ethnicity. While locally they are inspired by the thinking 
of Nik Abdul Aziz, internationally they are also influenced by the writings of Rached Ghannouchi, the leader of Tunisia's Ennahda movement.

The influence of Ghannouchi is important to note. This author was in Ghannouchi's monthly 'circle' (usrah) over a two-year period (1994-95) when Ghannouchi was living in exile in England. Even during that period, Ghannouchi was already calling for Islamists to change tack and adopt a strategy that is more policy-driven, inclusive and less legalistic. Ghannouchi firmly clarified his thinking more recently when he wrote that "Ennahda is now best understood not as an Islamist movement but as a party of Muslim democrats. We seek to create solutions to the day-to-day problems that Tunisians face rather than preach about the hereafter." ${ }^{57}$ This idea has been pursued further by several AMANAH leaders, especially the party's Strategy Director, Dzulkefly Ahmad.

Dzulkefly believes that the first conservative group of Malaysian political Islam activists - he calls them Gen-1 activists - failed in their quest to revive the Islamic state. As a result, political Islamism is now experiencing a generational change to create Gen-2, a group which holds a markedly different worldview and ideology. While Gen-1 is stuck in the conservative, legalistic, and exclusivist paradigm, Gen-2 believes that the modern-day challenges of a multi-racial society require an inclusive approach that acknowledges the need to present convincing arguments, including in a secular way, to win the democratic debate. In other words, they want to show the applicability and the relevance of Islamic political ideals through good policy propositions. Strategic and rational thinking are put at the forefront, reminiscent of the thinking once propagated by the Kaum Muda. ${ }^{58}$

The challenge for AMANAH is not just to develop a coherent and clear philosophy augmented by policy proposals, but to ensure the sustainability of the party in the long term. By positioning themselves as a political party, they must challenge the much more established PAS, who have dominated Malaysia's political Islam sphere for six decades. In these early days, AMANAH's main strategy seems focused on encouraging existing PAS members and voters to defect. Although it might be easy to persuade more progressive PAS members and supporters to change their vote, this is also a perilous strategy. In Malaysian electoral contests, whenever there are two or more candidates challenging the ruling Barisan Nasional coalition, it is more likely that the Barisan Nasional candidate will win because the opposition votes are split. Thus, if AMANAH were to contest in a constituency where PAS is already challenging UMNO, it is more likely that AMANAH's entry will boost UMNO's chances of winning. If this were to happen in the majority of seats contested by AMANAH, they risk being routed from national politics. Without representatives in the federal parliament, their ability to survive in the long-term is questionable. 
Nevertheless, parallel public discourses on political Islam reveal a palpable increase in progressive Islamist ideas among the public, especially after the creation of AMANAH. No longer monopolised by PAS, the Islamist agenda in Malaysia is witnessing the rise of new actors, the vast majority of whom are not affiliated to any political party, but are nevertheless quickly gaining recognition as public intellectuals and are regularly being cited when discussing Islam in today's Malaysia. Such oft-cited individuals include Maszlee Malik (former Associate Professor at the International Islamic University Malaysia), Muhamad Rozaime Ramle (Senior Lecturer at Sultan Idris Education University), Mohamad Asri Zainal Abidin (Mufti of the northern state of Perlis), Hasrizal Abdul Jamil (Director at Khalifah Model School), and Mohammad Redzuan Othman (Vice Chancellor of Universiti Selangor).

Several organisations are playing their roles too. The most active ones are the independent Islamic Renaissance Front (IRF) and Institut Darul Ehsan (IDE), an organisation sponsored by the Selangor state government. They organise regular events and publish original and translated books in Malay, which is a significant move to spread their ideas among a traditionally conservative Malay audience. The amount of available publications has also increased significantly with the entry of major new publishers like Ilham Books, as well as many other smaller publishing houses. At the international level, the Istanbul Network for Liberty, initially founded in Istanbul in 2011, has its head office in Kuala Lumpur following its registration as a Malaysian foundation in 2016.

\section{Concluding Remarks}

The new dynamics involving progressive Islamist public intellectuals, various organisations and publishing houses, mark a new step in the evolution of political Islam in Malaysia. The field is now more clearly divided between the conservatives and the progressives; the confusion that existed when they were working from within the same political party - PAS - no longer exists. Those who subscribe to conservative Islamism now know that their political vehicle is PAS, while those who are progressive can opt for AMANAH. The two will continue to carve out their own following, but there is an immediate risk to AMANAH because, if they fail to capture at least some victory at the polls, their long-term survival is at risk.

Nevertheless, the survival of progressive ideas is unlikely to be dependent solely on one political party. The splitting of PAS has sparked the growth of a broader interest in Islamist progressive ideas, with more discourses now taking place publicly, at all layers of society. Progressive Islamist civil society 
organisations are also becoming more vocal. The contestation that once existed between the Kaum Tua and Kaum Muda has been re-born in a new form. Even if AMANAH were to fail electorally, progressive Islamist ideas would likely remain as a force in the country.

\section{Policy Recommendations}

- PAS should adopt a political system based on the principle of the separation of powers, where authority is distributed between the executive (President and others). Majlis Syura Ulama should avoid autocratic leadership by creating a more transparent system based on a system of checks and balances.

- AMANAH is new and still crafting their progressive philosophy. AMANAH should therefore create its own think-tank as a clear projection of its views.

- Both PAS and AMANAH should create policy proposals that match their own philosophies and ideologies, to increase public trust.

- AMANAH should create a comprehensive strategic plan to ensure its sustainability in the political arena in Malaysia.

- Civil society organisations working in an environment of open and candid dialogue about Islam and public policy should be strengthened.

\section{Notes}

* During the time this article was written, Wan Saiful Wan Jan was associated with IDEAS Malaysia as Chief Executive Officer (between 2009 - Feb 2018) and with the Istanbul Network for Liberty as a chairman. Currently, he is the special advisor to the Ministry of Education in Malaysia and PTPTN Chairman. He can be reached through his email: wansaiful@gmail.com.

1. Gordon P. Means, 'The role of Islam in the political development of Malaysia,' Comparative Politics 1, no. 2 (1969): 264-84.

2. Farish A. Noor, Islam Embedded: The Historical Development of the PanMalaysian Islamic Party PAS (1951 - 2003) (Kuala Lumpur: Malaysian Sociological Research Institute, 2014).

3. Maszlee Malik, 'Theology in Malaysia: Between the Mainstream and the Periphery,' Hikma: Journal of Islamic Theology and Religious Education 4, no. 6 (2013): 51-65.

4. Mohamed Nawab Mohamed Osman, 'Towards a History of Malaysian Ulama,' South East Asia Research 16, no. 1 (2008): 117-40.

5. Azyumardi Azra, 'The Transmission of al-Manar's Reformism to the Malay- 
Indonesian World: The Cases of al-Imam and al-Munir,' Studia Islamika 6, no. 3 (1999): 75-100.

6. Shamsul Amri Baharuddin, 'Making Sense of the Plural-Religious Past and the Modern-Secular Present of the Islamic Malay World and Malaysia,'Asian Journal of Social Science 33, no. 2 (2005): 449-72.

7. Malik, 'Theology in Malaysia,' 51-65.

8. Baharuddin, 'Making Sense of the Plural-Religious Past,' 449-72.

9. Osman, 'Towards a History of Malaysian Ulama,' 129.

10. Riduan Mohd Nor, Pengaruh Pemikiran Ikhwanul Muslimin Terhadap Parti Islam Se-Malaysia (PAS) (n.p., 2004).

11. Noor, Islam Embedded, 75.

12. Syed Husin Ali, The Malays: Their Problems and Future (Kuala Lumpur: The Other Press, 2008).

13. Ismail Said, Menegak Agama Membela Bangsa: Perjuangan PAS 1951-1970 (Kuala Lumpur: Unit Buku Harakah, 2011), 90.

14. Kamarudin Jaffar, Burhanuddin Al Helmy: Pemikiran dan Perjuangan (Kuala Lumpur: IKDAS, 2000), 214.

15. Said, Menegak Agama Membela Bangsa, 151.

16. Ahmad Boestamam, Burhanuddin, Putera Setia Melayu Raya (Kuala Lumpur: Penerbitan Pustaka Kejora, 1972), 64.

17. Safie Ibrahim, The Islamic Party of Malaysia: Its Formative Stages and Ideology (Kelantan: Nuawi bin Ismail, 1981), 81-3.

18. Boestamam, Burhanuddin, Putera Setia Melayu Raya, 65-6.

19. Burhanuddin al-Helmy, 'Memperjuangkan dan Mengisi Kemerdekaan', in Islam dan Sosialisme, ed. Burhanuddin al-Helmy et al (Kuala Lumpur: Ikraq, 1988), 1-8.

20. Noor, Islam Embedded, 44.

21. Jaffar, Al Helmy: Pemikiran dan Perjuangan, 34.

22. Said, Menegak Agama Membela Bangsa.

23. S. Berman and D. Dettke, Understanding Social Democracy (Washington D.C.: Friedrich Ebert Stiftung, 2005)

24. Panel Pengkaji Sejarah, PAS Dalam Arus Perjuangan Kemerdekaan (Kuala Lumpur: Pusat Penyelidikan PAS, 1999).

25. Mujahid Yusof, Menuju PAS Baru: Krisis, Peluang dan Dinamisme (Kuala Lumpur: The Malaysian Insider, 2011), 52-5.

26. Communication with Salahuddin Ayob, Vice President of PAS (2009-2015), 16 April 2017.

27. Noor, Islam Embedded, 213-328.

28. Farish A. Noor, The Malaysian Islamic Party PAS 1951-2013: Islamism in a Mottled Nation (Amsterdam: Amsterdam University Press, 2014), 201.

29. Noor, Islam Embedded, 740.

30. Ibid., 395-6.

31. Communication with Salahuddin Ayob, Vice President of PAS (2009-2015), 16 April 2017.

32. Ibid.

33. Communication with Mujahid Yusof, PAS Central Committee Member (20052015), 15 April 2017. 
34. Communication with Salahuddin Ayob, Vice President of PAS (2009-2015), 16 April 2017.

35. Dzulkefly Ahmad, 'PAS and its 'Benevolent Nation' concept,' Dr Dzul. Available at: https://drdzul.com/2012/06/09/pas-and-its-benevolent-nationconcept/ (Accessed on: 29 March 2017).

36. Communication with Mujahid Yusof, PAS Central Committee Member (20052015), 15 April 2017.

37. Mujahid Yusof, Wajah Baru Politik Malaysia (Petaling Jaya: Anbakri Publika Sdn Bhd, 2009).

38. Mujahid Yusof, Menuju PAS Baru: Krisis, Peluang dan Dinamisme (Kuala Lumpur: The Malaysian Insider, 2011), 73-9.

39. Mujahid Yusof, Rejuvenasi PAS: Idea, Realiti, Aplikasi (Shah Alam: Ilham Centre, 2012), 117-23.

40. Communication with Salahuddin Ayob, Vice President of PAS (2009-2015), 16 April 2017.

41. Noor, The Malaysian Islamic Party PAS, 201.

42. 'Pas juga ada maruah,' Utusan Malaysia, 7 June 2015.

43. Translated from: "Sekarang ini saya terus terang, golongan profesional dominan, dia kuat dan boleh beri fakta-fakta menyebabkan keputusan tidak boleh dibuat. Sebab itulah kadang-kadang tok guru terpaksa buat keputusan sendiri. Beliau merujuk kepada Majlis Syura sahaja. Kalau dibawa kepada AJK Pusat, memang kalah..." Interview with Mahfodz Mohamad, 'Pas juga ada maruah,' Utusan Malaysia.

44. Haider Yutim, 'Kenyataan Hadi bukan pendirian rasmi PAS - Mat Sabu,' Astro Awani. Available at: $\mathrm{http} / / / \mathrm{www}$.astroawani.com/berita-politik/isu-mb-selangorkenyataan-hadi-bukan-pendirian-rasmi-pas-mat-sabu-40714. (Accessed on: 28 March 2017).

45. Khalid Samad, Dari PAS ke Amanah: Berani Berprinsip II (Petaling Jaya: Ilham Books, 2016).

46. Noor, The Malaysian Islamic Party PAS, 201.

47. Ahmad, 'PAS and its Benevolent Nation Concept,' 22.

48. Yusof, Wajah Baru Politik Malaysia.

49. W. J. Wan Saiful, 'Learn from the dynamic in PAS,' The Star, 19 August 2014.

50. Noor, The Malaysian Islamic Party PAS, 201.

51. Communication with Mohd Anuar Mohd Tahir, Secretary General of Parti Amanah Negara, 9 April 2017.

52. Translated from: "Kalau Tok Guru (Nik Abdul Aziz) masih ada, Tok Guru akan bersama saya...kerana apa yang dibawa oleh PAS sekarang lari daripada perjuangan Tok Guru Nik Aziz.” KiniTV, 'Kalau Tok Guru masih ada, dia akan ikut saya sertai AMANAH,' Youtube. Available at: https://www.youtube.com/ watch? $=01 \mathrm{SrHOgZTBg}$ (Accessed on: 10 April 2017).

53. Ahmad Awang, Speech delivered at Seminar Pemikiran Tuan Guru Nik Abdul Aziz Nik Mat, organised by Parti Amanah Negara at the Kuala Lumpur and Selangor Chinese Assembly Hall, 9 April 2017.

54. Translated from: "mengatakan seperti kata-kata yang pernah diucapkan oleh seorang pimpinan PAS dari Terengganu yang dipopularkan ... sebagai 'amanat Tok Guru Haji Hadi'” 
55. Parti Amanah Negara, Constitution of Parti Amanah Negara (n.p., 2016).

56. Communication with Maszlee Malik, 15 April 2017.

57. Rached Ghannouchi, 'From Political Islam to Muslim Democracy: The Ennahda Party and the future of Tunisia,' Foreign Affairs. Available at: https:// www.foreignaffairs.com/articles/tunisia/political-islam-muslim-democracy (Accessed on: 29 March 2017).

58. Dzulkefly Ahmad, 'Membangun Pemikiran Dinamis Generasi Kedua Politikal Islam,' in Generasi Kedua Politikcal Islam: Wacana Baru Gerakan Islam Jilid 1, ed. Maszlee Malik and Zulkifli Hassan (Petaling Jaya: Ilham Books, 2016): $15-65$. 